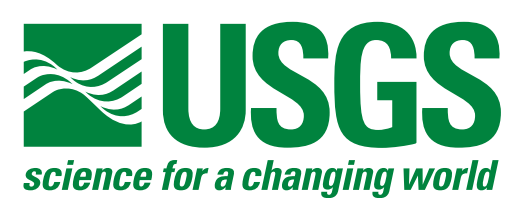

\title{
Seismic Profile Analysis of Sediment Deposits in Brownlee and Hells Canyon Reservoirs Near Cambridge, Idaho
}

By James Flocks, Kyle Kelso, Ryan Fosness, Chris Welcker

Open-File Report 2014-1019

U.S. Department of the Interior

U.S. Geological Survey 


\section{U.S. Department of the Interior \\ SALLY JEWELL, Secretary}

\section{U.S. Geological Survey \\ Suzette M. Kimball, Acting Director}

U.S. Geological Survey, Reston, Virginia: 2014

For more information on the USGS-the Federal source for science about the Earth, its natural and living resources, natural hazards, and the environment-visit http://www.usgs.gov or call 1-888-ASK-USGS

For an overview of USGS information products, including maps, imagery, and publications, visit http://www.usgs.gov/pubprod

To order this and other USGS information products, visit http://store.usgs.gov

Any use of trade, firm, or product names is for descriptive purposes only and does not imply endorsement by the U.S. Government.

Although this information product, for the most part, is in the public domain, it also may contain copyrighted materials as noted in the text. Permission to reproduce copyrighted items must be secured from the copyright owner.

Suggested citation:

Flocks, James, Kelso, Kyle, Fosness, Ryan, and Welcker, Chris, 2014, Seismic profile analysis of sediment deposits in Brownlee and Hells Canyon Reservoirs near Cambridge, Idaho: U.S. Geological Survey Open-File Report 2014-1019, 14 p., http://dx.doi.org/10.3133/ofr20141019

ISSN 2331-1258 (online) 


\section{Contents}

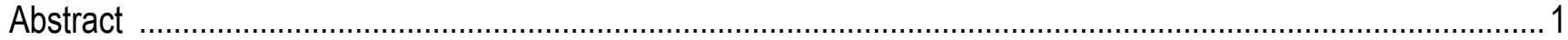

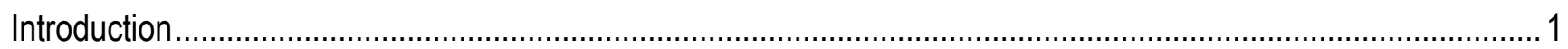

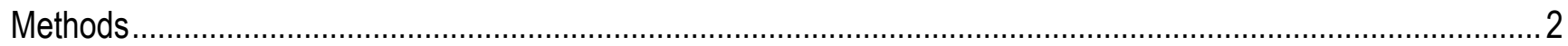

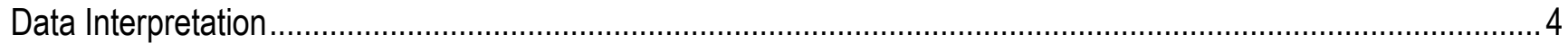

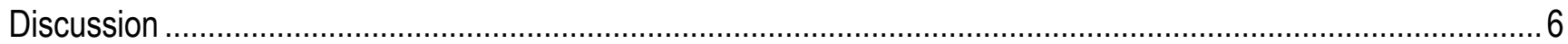

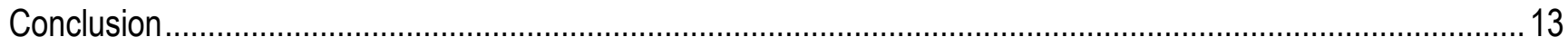

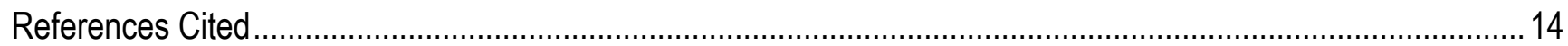

\section{Figures}

1. An index map displaying geophysical tracklines (purple lines) acquired in Brownlee and Hells Canyon

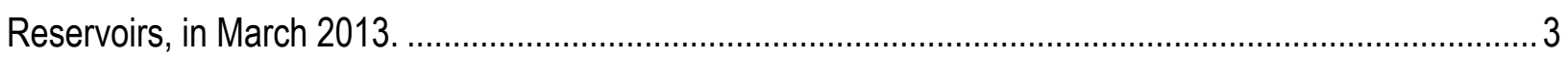

2. An example of a chirp profile from Brownlee Reservoir showing the attributes detected by the system ....... 5

3. The water-sediment (Horizon A), and sediment-substrate (Horizon B) reflectors were isolated using conditional filters that for each trace $\left(T_{\text {tn }}\right)$ compares sets of neighboring samples $\left(\mathrm{S}_{\text {snt }}\right)$ for a qualifying increase in amplitude

4. Point distribution of isopach (sediment thickness) values along the survey tracklines covering the northern segment of Brownlee Reservoir.

5. Isopach maps of recent sediment deposition within Brownlee and Hells Canyon Reservoirs were derived from calculating the thickness between Horizons $A$ and $B$ interpreted and digitized from chirp profiles ........ 8

6. Top right: photograph (looking south) of the Snake River valley prior to dam construction located at the confluence with the Powder River

7. A seismic profile (right) collected over a submerged alluvial fan (represented by outward curving contours on the map to the left) shows no signal return at depth, indicating that the rocky composition has reflected the acoustic signal

8. Gravity cores collected from deeper areas of Brownlee Reservoir yielded 0.75 meters of highly fluid muds.

9. The valley walls at the waterline within the reservoirs show rock exposed during lake level fluctuations. During inundation, wave action scours the thin layer of soil from the rock surface and the sediment is deposited at lower elevations in areas of low relief

\section{Tables}

1. Grid statistics for the Brownlee and Hells Canyon Reservoir isopachs 


\section{Conversion Factors}

\section{SI to Inch/Pound}

\begin{tabular}{|c|c|c|}
\hline Multiply & By & To obtain \\
\hline \multicolumn{3}{|c|}{ Length } \\
\hline centimeter $(\mathrm{cm})$ & 0.3937 & inch (in.) \\
\hline millimeter (mm) & 0.03937 & inch (in.) \\
\hline meter (m) & 3.281 & foot (ft) \\
\hline kilometer (km) & 0.6214 & mile (mi) \\
\hline kilometer (km) & 0.5400 & mile, nautical (nmi) \\
\hline meter $(\mathrm{m})$ & 1.094 & yard $(y d)$ \\
\hline \multicolumn{3}{|c|}{ Area } \\
\hline square centimeter $\left(\mathrm{cm}^{2}\right)$ & 0.001076 & square foot $\left(\mathrm{ft}^{2}\right)$ \\
\hline square meter $\left(\mathrm{m}^{2}\right)$ & 10.76 & square foot $\left(\mathrm{ft}^{2}\right)$ \\
\hline square centimeter $\left(\mathrm{cm}^{2}\right)$ & 0.1550 & square inch $\left(\mathrm{ft}^{2}\right)$ \\
\hline \multicolumn{3}{|c|}{ Volume } \\
\hline liter (L) & 33.82 & ounce, fluid (fl. oz) \\
\hline liter $(\mathrm{L})$ & 2.113 & pint (pt) \\
\hline liter $(\mathrm{L})$ & 1.057 & quart (qt) \\
\hline liter (L) & 0.2642 & gallon (gal) \\
\hline cubic meter $\left(\mathrm{m}^{3}\right)$ & 264.2 & gallon (gal) \\
\hline cubic meter $\left(\mathrm{m}^{3}\right)$ & 35.31 & cubic foot $\left(\mathrm{ft}^{3}\right)$ \\
\hline cubic meter $\left(\mathrm{m}^{3}\right)$ & 1.308 & cubic yard $\left(\mathrm{yd}^{3}\right)$ \\
\hline cubic kilometer $\left(\mathrm{km}^{3}\right)$ & 0.2399 & cubic mile $\left(\mathrm{mi}^{3}\right)$ \\
\hline \multicolumn{3}{|c|}{ Flow rate } \\
\hline cubic meter per second $\left(\mathrm{m}^{3} / \mathrm{s}\right)$ & 70.07 & acre-foot per day (acre-ft/d) \\
\hline meter per second $(\mathrm{m} / \mathrm{s})$ & 3.281 & foot per second $(\mathrm{ft} / \mathrm{s})$ \\
\hline $\begin{array}{l}\text { cubic meter per second per square kilometer } \\
\qquad\left[\left(\mathrm{m}^{3} / \mathrm{s}\right) / \mathrm{km}^{2}\right]\end{array}$ & 91.49 & $\begin{array}{l}\text { cubic foot per second per square mile } \\
{\left[\left(\mathrm{ft}^{3} / \mathrm{s}\right) / \mathrm{mi}^{2}\right]}\end{array}$ \\
\hline
\end{tabular}

Temperature in degrees Celsius $\left({ }^{\circ} \mathrm{C}\right)$ may be converted to degrees Fahrenheit $\left({ }^{\circ} \mathrm{F}\right)$ as follows:

$$
{ }^{\circ} \mathrm{F}=\left(1.8 x^{\circ} \mathrm{C}\right)+32
$$

Temperature in degrees Fahrenheit $\left({ }^{\circ} \mathrm{F}\right)$ may be converted to degrees Celsius $\left({ }^{\circ} \mathrm{C}\right)$ as follows:

$$
{ }^{\circ} \mathrm{C}=\left({ }^{\circ} \mathrm{F}-32\right) / 1.8
$$

Horizontal coordinate information is referenced to the North American Datum of 1983 (NAD 83),

Universal Transverse Mercator (UTM) Zone 11 


\section{Acknowledgments}

Funding for this study was provided by the USGS Coastal and Marine Geology Program (CMPG), the Idaho Water Science Center (IWSC), and the Idaho Power Company. We appreciated the help with document organization provided by Betsy Boynton (contractor). Reviews from Chris Reich and Karen Morgan from the USGS St. Petersburg Coastal and Marine Science Center, contributed greatly to the creation of this report. 


\title{
Seismic Profile Analysis of Sediment Deposits in Brownlee and Hells Canyon Reservoirs Near Cambridge, Idaho
}

James Flocks, Kyle Kelso, Ryan Fosness, and Chris Welcker

\begin{abstract}
The U.S. Geological Survey (USGS) St. Petersburg Coastal and Marine Science Center, in cooperation with the USGS Idaho Water Science Center and the Idaho Power Company, collected high-resolution seismic reflection data in the Brownlee and Hells Canyon Reservoirs, in March of 2013. These reservoirs are located along the Snake River, and were constructed in 1958 (Brownlee) and 1967 (Hells Canyon). The purpose of the survey was to gain a better understanding of sediment accumulation within the reservoirs since their construction. The chirp system used in the survey was an EdgeTech Geo-Star Full Spectrum Sub-Bottom (FSSB) system coupled with an SB-424 towfish with a frequency range of 4 to $24 \mathrm{kHz}$. Approximately 325 kilometers of chirp data were collected, with water depths ranging from 0-90 meters. These reservoirs are characterized by very steep rock valley walls, very low flow rates, and minimal sediment input into the system. Sediments deposited in the reservoirs are characterized as highly fluid clays. Since the acoustic signal was not able to penetrate the rock substrate, only the thin veneer of these recent deposits were imaged. Results from the seismic survey indicate that throughout both of the Brownlee and Hells Canyon reservoirs the accumulation of sediments ranged from 0 to $2.5 \mathrm{~m}$, with an average of $0.5 \mathrm{~m}$. Areas of above average sediment accumulation may be related to lower slope, longer flooding history, and proximity to fluvial sources.
\end{abstract}

\section{Introduction}

Brownlee and Hells Canyon Reservoirs are located along the Idaho-Oregon border and are part of the Hells Canyon Complex (HCC) of the Snake River, one of the largest rivers in the Pacific Northwest (fig. 1). Brownlee Reservoir is 93 kilometers (km) long and less than $1 \mathrm{~km}$ wide, with very steep rock valley walls. Water depths in the reservoir can exceed 91 meters (m), with water-level elevations ranging from 614 to $633 \mathrm{~m}$ above sea level (years 2010-2011). The reservoir began to fill when the Brownlee Dam was completed in 1958. Reservoir depths, or pool elevations, fluctuate yearly with flooding, controlled drawdowns, and upstream water diversions. Prior to dam construction, the Snake River within the HCC was characterized by high flow rates, and early topographic maps show numerous areas of rapids. A major tributary to the reservoir is the Powder River, located approximately $16 \mathrm{~km}$ south (upstream) of the dam. Hells Canyon Reservoir is $40 \mathrm{~km}$ long with a maximum water depth of $76 \mathrm{~m}$ and is the deepest river gorge in North America, with ridge tops that exceed 1,500 $\mathrm{m}$ above the channel floor (Miller and others, 2003). The river within the gorge had high flow rates and rapids until 1967, when construction of the Hells Canyon Dam was completed. Hells Canyon Reservoir experiences much less water fluctuation than Brownlee Reservoir, with only $1.5 \mathrm{~m}$ variation in 2010 and 2011.

The steep valley walls within the HCC are created by resistant metamorphic and volcanic rocks, covered by a thin soil mantle and rock talus. The rapid downcutting of the river (due to regional tectonic uplift over the past 3 million years) led to generally straight gorges that are believed to follow northnortheast trending fault zones (Miller and others, 2003). Sediment accumulation within the reservoirs is 
derived mainly through erosion of the valley walls (local erosion) and upstream sources. Sedimentation from upstream sources far outweighed local erosion but has been significantly restricted due to water regulation and storage. At the time of construction of the Brownlee reservoir dam, 87 percent of the upstream drainage area that otherwise would deliver sediments through the HCC had already been cut off by numerous dams and reservoirs (Miller and others, 2003). Due to the drastically changing hydrologic processes, sediment deposition since flooding of the Brownlee and Hells Canyon Reservoirs is poorly understood. This study is part of a larger effort to quantify the physical characteristics and distribution of sediments within the reservoirs. This investigation utilizes an acoustic source (chirp subbottom profiling) that remotely images sediment thickness and distribution, ultimately to map and quantify sediment accumulation within the reservoir.

\section{Methods}

The geophysical data collected for this project are presented in the U.S. Geological Survey (USGS) Data Series report by Forde and others (in press), as well as a description of the equipment and processing steps used to produce the data. The methods section of this report provides only a summary. Approximately $322 \mathrm{~km}$ of high-resolution chirp subbottom data were collected in Brownlee Reservoir and $103 \mathrm{~km}$ in Hells Canyon Reservoir from March 16 to March 31, 2013 (fig. 1). The data were collected onboard a 7.5-m aluminum research vessel. The vessel maintained a speed between 1.5 and 2.5 meters per second $(\mathrm{m} / \mathrm{s})$. Winter months were chosen to conduct the survey in order to avoid a significant thermocline in the water column and formation of biogenic gas in the sediments, both of which could inhibit the chirp signal response. The chirp system used in the survey was an EdgeTech Geo-Star Full Spectrum Sub-Bottom (FSSB) system coupled with an SB-424 towfish (frequency range of 4 to $24 \mathrm{kHz})$. Vertical resolution is $4-8$ centimeters $(\mathrm{cm})$. The horizontal resolution at the lake bottom is dependent on water depth and signal wavelength. The average diameter of the signal footprint ranged from approximately 6 to $14 \mathrm{~m}$ in $10 \mathrm{~m}$ and $50 \mathrm{~m}$ of water, respectively. Due to the high relief within the reservoirs this sometimes produced false echos in the profile as the signal footprint imaged the lake bottom at different depths. EdgeTech Discover software was used to control the Geo-Star topside unit and digitally log trace data in the EdgeTech proprietary format (EdgeTech, 2011). The data were converted to the Society of Exploration Geophysicists Y (SEG Y), revision 1, the standard format for processing (Norris and Faichney, 2002). The SB-424 towfish was towed astern of the port side of the vessel. Although variable, in Brownlee Reservoir the towfish was typically towed $20 \mathrm{~m}$ behind the vessel, at a depth of approximately $8 \mathrm{~m}$. In Hells Canyon Reservoir the towfish was towed close to the stern of the vessel in approximately $1 \mathrm{~m}$ of water. The geographic location of the vessel was determined using Differential Global Positioning System (DGPS) navigation.

Visual output from the chirp system represents data in a two-dimensional trackline profile. The survey consisted of three shore-parallel tracklines along the length of the reservoirs: one along each bank, and a central trackline that follows the old river channel (thalweg). A fourth line followed a zigzag pattern to provide a tie-line across the parallel lines and covered as much area as possible between the lines (fig. 1). Post-processing of the data included applying a vertical gain to the data in order to enhance deeper reflectors, and extracting navigation data from the SEG Y files and converting them to the Universal Transverse Mercator (UTM) coordinate system, zone 11. 

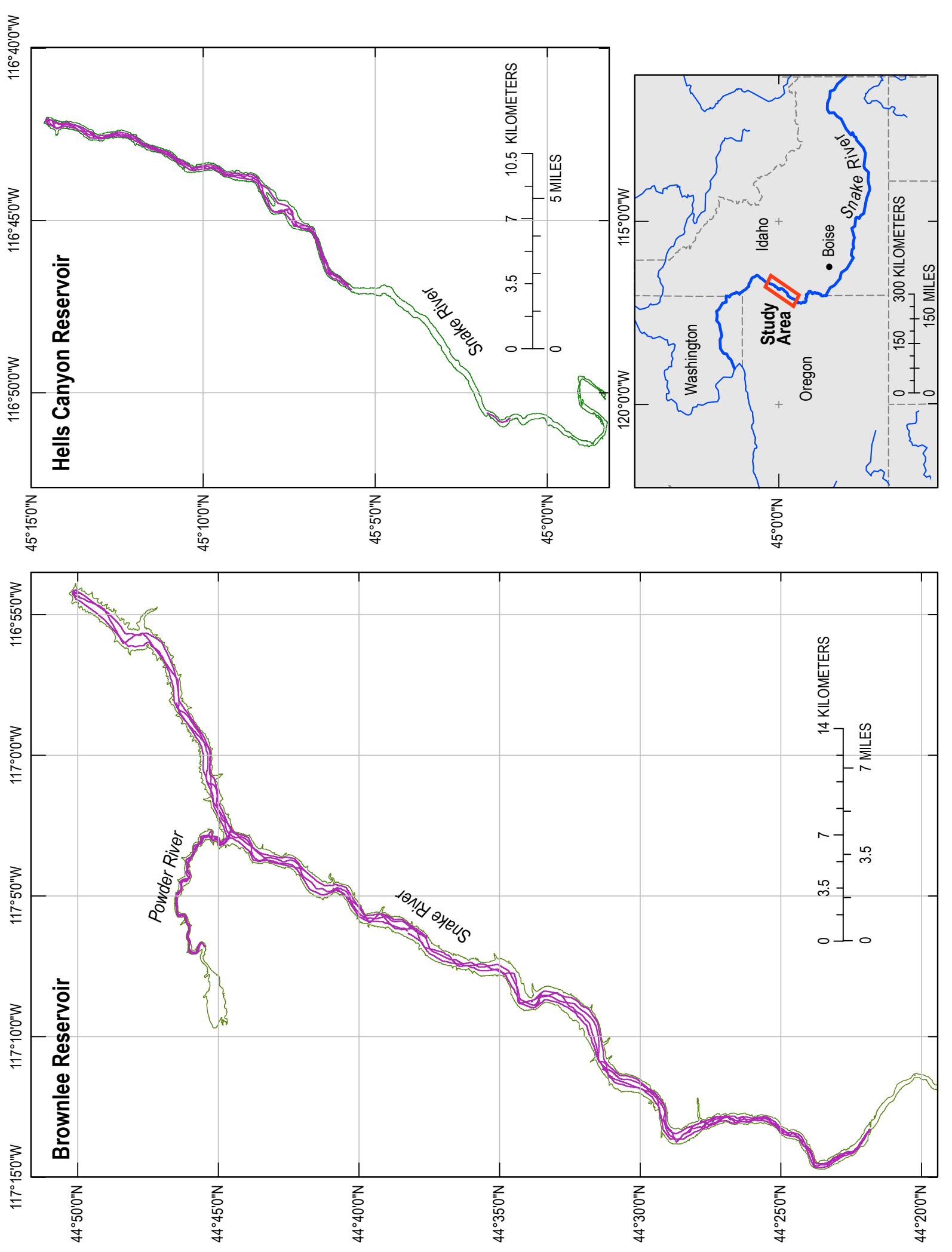

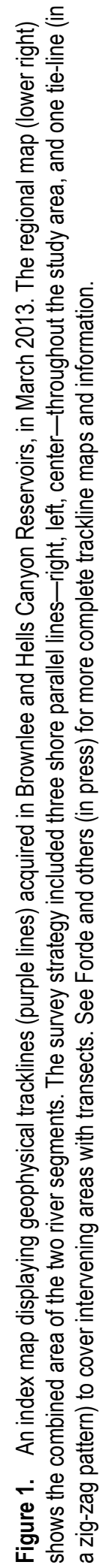




\section{Data Interpretation}

The seismic profiles were imported into the OpendTect open source seismic interpretation system for visualization and interpretation. Seismic profiles are represented by two fields: the horizontal and vertical fields. The vertical field displays the two-way travel time, in milliseconds (ms), of the acoustic signal. The horizontal field displays the amplitude of the signal response. The amplitude of the acoustic response within the substrate is proportional to density changes across stratigraphic horizons. The objective of the study is to characterize the accumulation of post-construction reservoir sediments on top of underlying rocky substrate within the reservoirs. Post-construction reservoir sediment deposits are constrained by two target horizons: the water-sediment interface (Horizon A), and the base of the most recently accumulated material (sediment to rock substrate interface, Horizon B), which also produce the highest magnitude density change in the profile (fig. 2). Signal amplitude increases by a factor of about 15 between the water and sediments, and by a factor of about 30 between the sediments and substrate. The high-amplitude shift across these boundaries allows them to be isolated from the rest of the profile by setting conditional criteria along each trace that detects the depth where shifts occur. For example, if the amplitude for a series of trace samples $\left(\mathrm{T}_{\mathrm{tn}}\right)$ is less than half the amplitude of neighboring samples $\left(\mathrm{S}_{\text {sntf }}\right)$, then the samples can be considered the water-sediment interface. In this survey each trace sample represents 23 microseconds (um), or approximately $3 \mathrm{~cm}$. A sample range of $20 \mathrm{~cm}$ was analyzed to detect the water to sediment and sediment to substrate interfaces. If the amplitude ranges met the target criteria, then the water to sediment surface was assigned an intermediate amplitude, and the sediment to substrate a high amplitude. All samples that did not meet the criteria were assigned low amplitudes. This procedure produced a profile that isolated the water to sediment and sediment to substrate interfaces from the raw profile (fig. 3). The process provides quantifiable criteria to define the two horizons and improves the ability to convert data into two-dimensional surfaces, or horizons. In this report the sediment to water interface will be referred to as Horizon A, and the sediment to substrate interface as Horizon B (fig. 2).

Using the OpendTect software, the two horizons interpreted from the data are converted into two-dimensional lines; the horizontal field is referenced in geographic space (displayed in NAD83, UTM zone $11 \mathrm{~N}$ ), and the vertical field in two-way travel time of the acoustic signal (displayed in milliseconds, ms). Once the horizons for each trackline in the dataset were digitized, they were exported as an ascii table displaying geographic positions (X, Y; in meters), and depth (Z; in ms). Depth was converted from milliseconds to meters using a speed of sound in water value of $1,500 \mathrm{~m} / \mathrm{s}$. Trackline number and trace number are also included in the output. The distance between Horizon B and Horizon A at each trace provides the thickness of recent sediment accumulations (fig. 3). During the digitizing process some traces were skipped, and the number of missing traces varies between horizons. In some lines traces were skipped at either end of the line, and occasionally a few traces within the profile were not included. Although the skipped traces represent an insignificant percentage compared to the whole profile. A filter was developed to do a trace-by-trace comparison between horizons to ensure trace $n$ from Horizon B was indeed being differentiated from trace $n$ in Horizon A. For each trackline, the filter systematically picked a trace number for horizon A and searched the entire dataset of horizon B for a match. Where matches were not found, the traces for both horizons were excluded from the output. From the seismic profiles 555,038 matches were selected for a 46 square kilometer $\left(\mathrm{km}^{2}\right)$ area of Brownlee Reservoir; 140,759 matches were selected for a $6 \mathrm{~km}^{2}$ area of Hells Canyon Reservoir. 


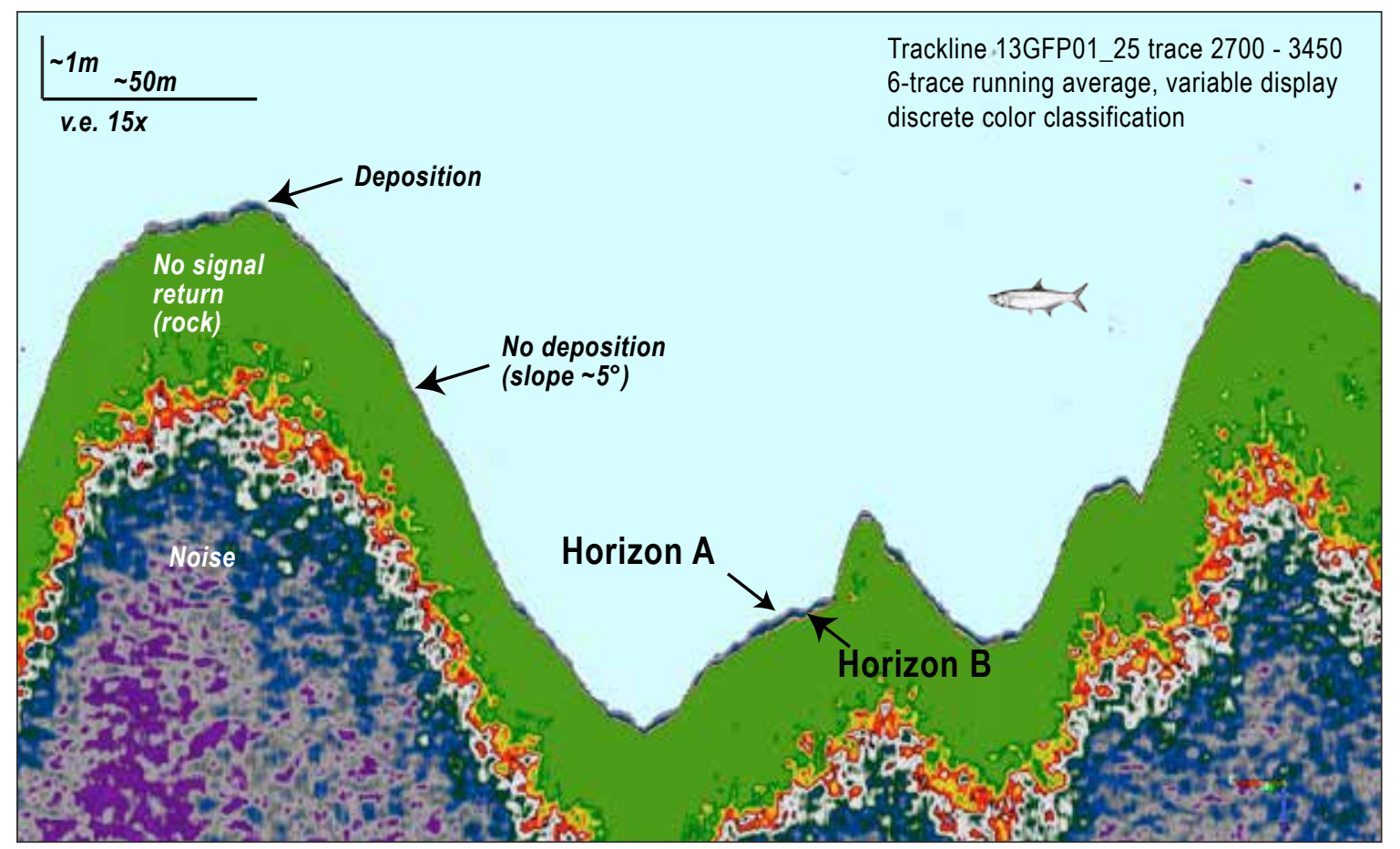

Figure 2. An example of a chirp profile from Brownlee Reservoir showing the attributes detected by the system. The first visible reflector (Horizon $A$ ) is between the water column and the reservoir bottom and the second visible reflector (Horizon $B$ ) is likely between the thin veneer of recent sediment accumulation and underlying rock substrate. The acoustic signal was unable to penetrate the rock substrate, so no other reflectors were detected. The deposit between horizons A and B appears on horizontal surfaces and diminishes in areas of vertical relief.
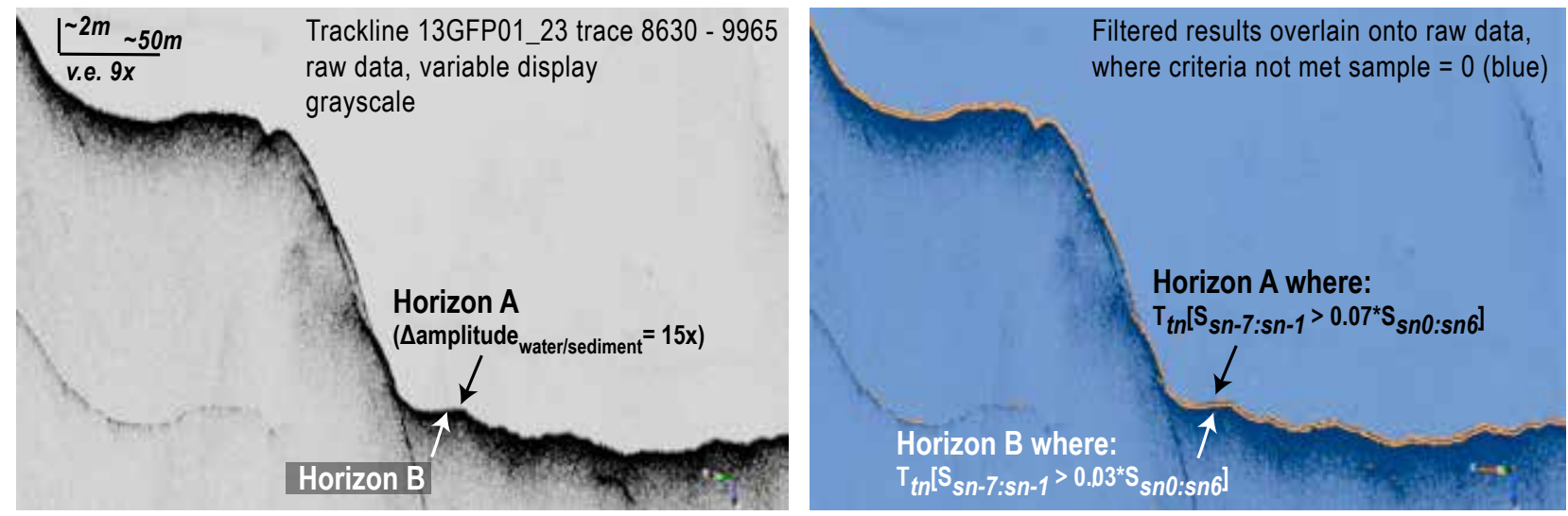

Figure 3. The water-sediment (Horizon A), and sediment-substrate (Horizon B) reflectors were isolated using conditional filters that for each trace $\left(\mathrm{T}_{\mathrm{tn}}\right)$ compares sets of neighboring samples $\left(\mathrm{S}_{\text {snft }}\right)$ for a qualifying increase in amplitude. Samples within Horizon $A$ were assigned an intermediate value, samples within Horizon B a high value, and samples that did not meet the criteria were assigned a low value.

An output file was generated from the derived thickness values for each reservoir, which contained both geographic position (UTM, zone 11N), and sediment thickness or isopach, in meters (fig. 4). This dataset was then gridded into a three-dimensional surface using the Generic Mapping Tools (GMT) software package. First, line data were block-averaged to $20 \mathrm{~m}$ using the blockmean filter in GMT, 
which smoothes the curvature of the block-averaged surface. The output was then gridded to a surface using the surface algorithm in GMT, with a 160-m search radius, 0.5 tension, where tension is a factor between 0 and 1 and suppresses spurious oscillations, and an upper limit equal to the highest thickness value found in the line data. Since the surface filter grids a rectangular area that does not represent the actual shorelines of the reservoir, areas of the grid outside the reservoir shorelines were clipped using shoreline files digitized from aerial imagery (provided by the Idaho Power Company). Grid nodes outside of the reservoir were assigned "No Data" values. The statistics on the isopach grids for Brownlee and Hells Canyon Reservoirs are shown in table 1. Since Brownlee Reservoir experiences significant drawdowns from the full pool elevation of $634 \mathrm{~m} \mathrm{(2,080} \mathrm{feet,} \mathrm{ft),} \mathrm{additional} \mathrm{volume} \mathrm{statistics} \mathrm{were}$

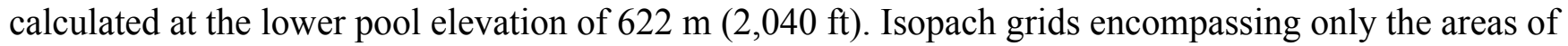
the original Snake River channel were also calculated. For Brownlee and Hells Canyon Reservoirs these channels were digitized from pre-dam topographic maps and may contain some riparian areas. Finally, the isopach grids were imported into ArcMap and converted to ERDAS Imagine files. The isopach maps are presented in figure 5.

Table 1. Grid statistics for the Brownlee and Hells Canyon Reservoir isopachs. Two pool elevations for Brownlee Reservoir are provided: full pool (elevation $2080 \mathrm{ft}$ or $634 \mathrm{~m}$ ), and $12 \mathrm{~m}$ drawdown (elevation $2040 \mathrm{ft}$ or $622 \mathrm{~m}$ ). Brownlee Channel and Hells Canyon Channel statistics represent isopachs restricted to the original river channel, digitized by the Idaho Power Company from pre-dam topographic maps.

[m, meter; $\mathrm{m}^{3}$, cubic meter; $\mathrm{km}^{2}$, square kilometer]

\begin{tabular}{|c|c|c|c|c|c|c|c|}
\hline & x/y cell size & Grid nodes & Grid nodes & Area & Volume & $\begin{array}{c}\text { Volume } \\
\text { per unit area }\end{array}$ & $\begin{array}{l}\text { Maximum } \\
\text { thickness }\end{array}$ \\
\hline Grid Area & (m) & (x) & (y) & $\left(\mathrm{km}^{2}\right)$ & $\left(\mathrm{m}^{3}\right)$ & $\left(\mathrm{x} 10^{6} \mathrm{~m}^{3} / \mathrm{km}^{2}\right)$ & (m) \\
\hline Brownlee 2080 & 10 & 2,731 & 5,251 & 45.68 & $20,863,700$ & 0.46 & 2.72 \\
\hline Brownlee 2040 & 10 & 2,729 & 5,251 & 35.84 & $16,132,400$ & 0.45 & 2.72 \\
\hline Brownlee Channel & 10 & 2,716 & 5,251 & 9.18 & $3,331,950$ & 0.36 & 2.08 \\
\hline Hells Canyon & 5 & 1,311 & 3,301 & 5.63 & $3,115,220$ & 0.55 & 2.66 \\
\hline Hells Canyon Channel & 5 & 1,310 & 3,260 & 1.22 & 578,267 & 0.47 & 2.50 \\
\hline
\end{tabular}

\section{Discussion}

The acoustic signal of the chirp system does not have the capacity to penetrate the basalt and metamorphic substrate that floors the river valleys. Near total reflection of the acoustic signal at the rock surface produces a uniformly opaque image in the seismic profiles (fig. 2). Historic photographs of the river valley prior to dam construction provide useful comparisons to what is imaged in the seismic profile. Figure 6 shows a railroad (RR) grade that ran along the former Snake River at the confluence with the Powder River. A seismic profile through the area images the original river valley and the steep banks of the river valley on either side of the railroad grade. Both the photograph and seismic profile do not show significant amounts of sediment deposits along the rocky slopes. Slope angles of the valley walls are typically very high; extreme angles up to 65 degrees have been measured within the submerged portion of the valley.

Similarly, the acoustic signal is unable to penetrate areas of the river valley composed of known clastic deposition. Figure 7 identifies a former alluvial fan (represented as a contour map) that is now submerged. On land the apex of the fan coincides with a stream valley entering the reservoir. A seismic profile that crosses the alluvial fan shows the same opaque image at depth, with only a thin veneer of 


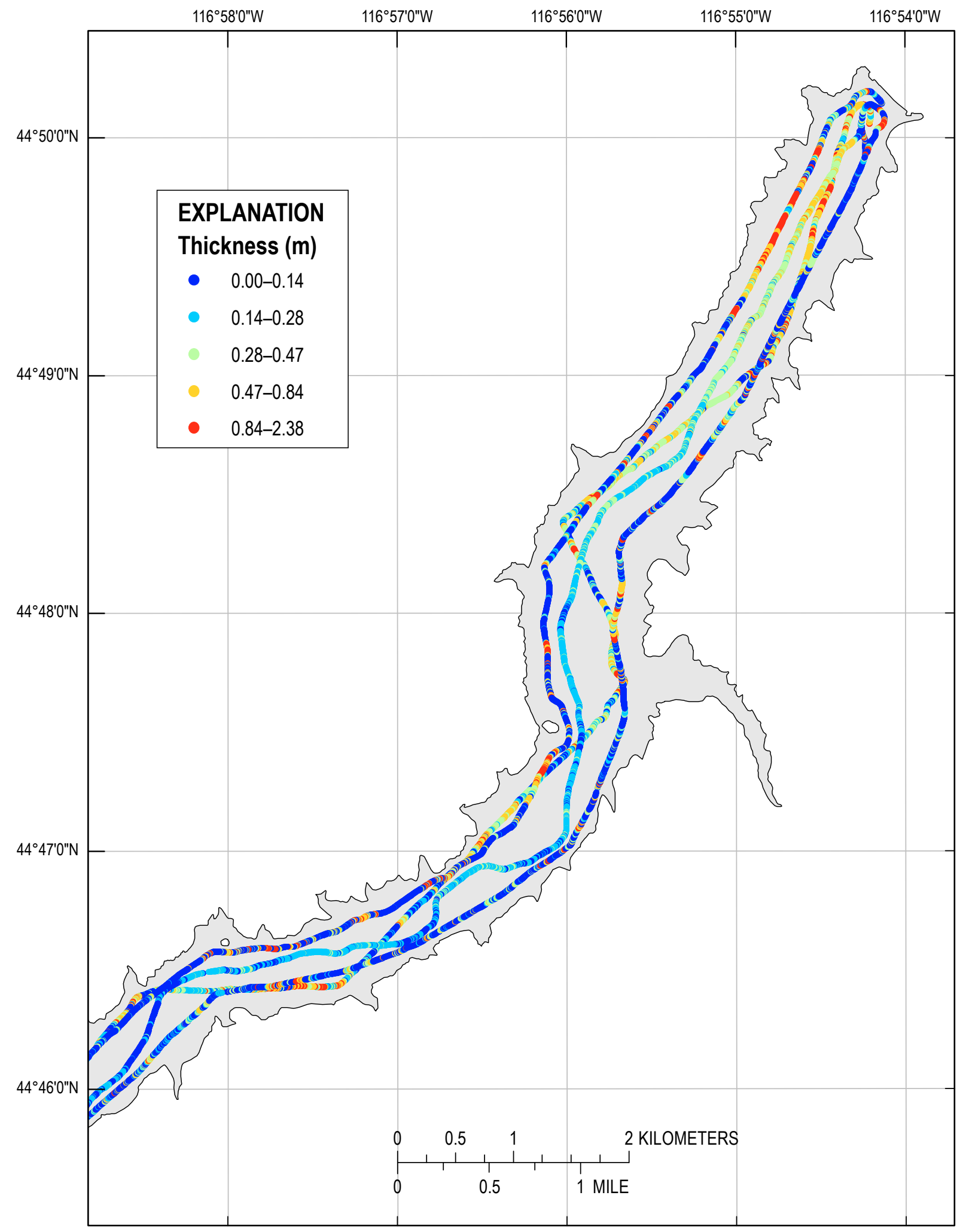

Figure 4. Point distribution of isopach (sediment thickness) values along the survey tracklines covering the northern segment of Brownlee Reservoir. The points averaged 2 meters apart along tracklines, and trackline spacing ranged from 200 meters to 400 meters. 

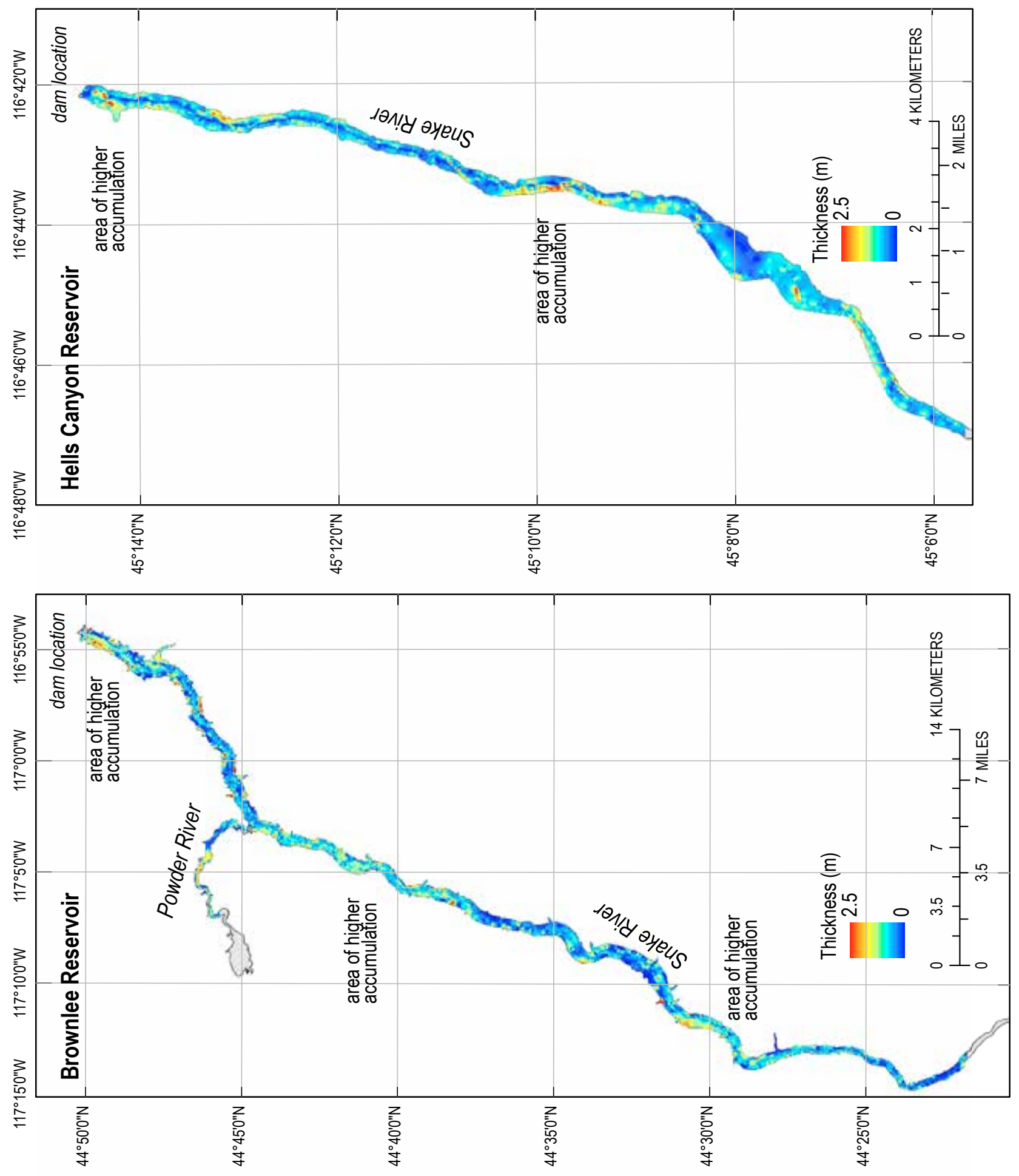

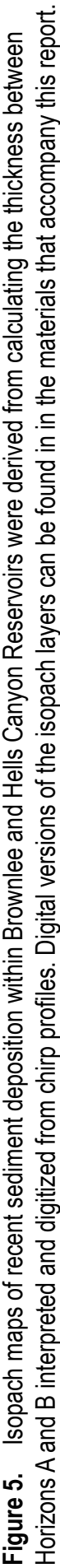


deposition present at the surface. It is likely that the rocky composition of the alluvial deposits significantly reflects the signal of the chirp system. A more substantial seismic profiling system would be necessary to penetrate these deposits. The thin layer atop the alluvial deposits corresponds to the veneer of deposition seen in other profiles (fig. 2). Core samples taken from these sediments indicate that they are highly fluid, organic muds with very little to no sand content (fig. 8). The sediments are likely derived from upstream sources and the valley walls. Miller and others (2003) find that 70 percent of the sediments within the HCC reservoirs are derived from upstream sources. Prior to construction of the reservoir, 87 percent of the upstream watershed was blocked by other dams, significantly reducing the primary source of sediments. On the valley walls, only a thin veneer of sediments cover the rock substrate (fig. 9), and soil production in the semiarid region is not high. These factors suggest that very little sediment has been introduced to the system over the life of the reservoir. Prior to the dam's construction, the swift current of the Snake River likely maintained a minimal sediment budget within the valley, leaving few deposits after dam construction was completed. These remaining sediments would have been redistributed during high flow events at early drawdowns of the reservoir. With very little clastic
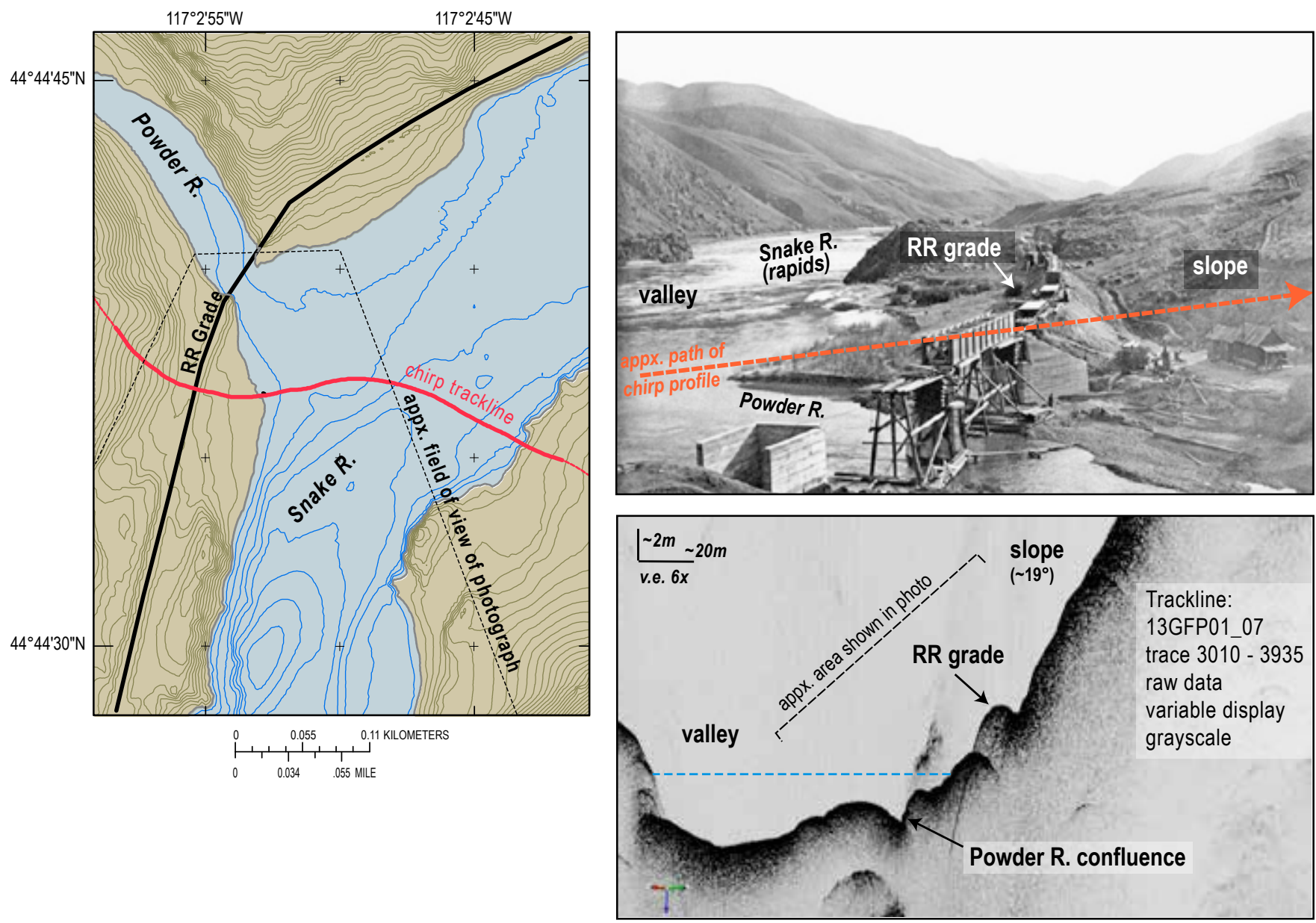

Figure 6. Top right: photograph (looking south) of the Snake River valley prior to dam construction located at the confluence with the Powder River. Bottom right: a seismic profile collected across the former scene shows the morphologic features evident in the photograph. The profile runs across the river valley, over the railroad grade and up the valley wall. Neither image shows significant fluvially derived deposits, suggesting low initial in situ sediment loads in the system. Left: The field of view of the photograph and the location of the chirp trackline. Photograph from the Baker County (Oregon) Library. 
input, present sedimentation within the central part of the reservoirs is through suspension-settling of fine-grained material. The sediments drape the flat surfaces of the valley floor and, due to lack of currents in the deep waters, are not resuspended. Results from the seismic survey indicate that throughout both the HCC reservoirs the accumulation of sediments range from 0 to $2.5 \mathrm{~m}$, with an average of $0.5 \mathrm{~m}$. Volume of sediment per unit area is slightly higher in Hells Canyon $\left(0.55 \times 10^{6} \mathrm{~m}^{3} / \mathrm{km}^{2}\right)$ than Brownlee $\left(0.46 \times 10^{6} \mathrm{~m}^{3} / \mathrm{km}^{2}\right)$.

Brownlee Reservoir experiences frequent water-level drawdowns and long durations with pool elevation lower than the full pool elevation of $634 \mathrm{~m}$ (2,080 ft.). To evaluate the effects of a smaller pool area on sediment distribution, the isopach grid was reduced by 21 percent to a pool elevation of $622 \mathrm{~m}$ $(2,040 \mathrm{ft}$.). The resulting sediment volume quantity was reduced by a similar amount (23 percent), so the volume per unit area did not change significantly. However, further reducing the grid to an area constrained by the original river channel boundary results in a 20-percent decrease in the volume per unit area (table 1). Similarly, for Hells Canyon Reservoir, reducing the grid area to the original river channel reduced the volume per unit area by 14 percent.

Recent sediment accumulation is dependent on slope angles, as most of the sediment deposits are in areas with comparably low relief, with little or no accumulation appearing on the steep valley walls (fig. 9). During water level fluctuations, areas of higher relief experience longer durations of wave activity, increasing erodibility and sediment redistribution. Interestingly, overall sediment accumulation appears to thin within the original river channel relative to the flanks (table 1). These flank areas include the river flood plain, which is naturally low in relief and closer to material eroding from the valley walls, and other local sources such as sidewall streams. The volume of material directly deposited from these local sources can be estimated as the difference between suspension deposition and total accumulation, assuming that deposition through the settling of fine-grained material out of suspension is generally uniform throughout the reservoir. If the original river channel in Brownlee Reservoir occupies the central portion of the valley, and the sediment accumulation in the channel largely represents suspension deposits, then the difference in accumulation per unit area $\left(0.1 \times 10^{6} \mathrm{~m}^{3} / \mathrm{km}^{3}\right)$ for the entire reservoir can be considered directly contributed by local sources. This amounts to $4.57 \times 10^{6} \mathrm{~m}^{3}$ of material (table 1). Thus, approximately 22 percent of the post-construction dam sedimentation is derived through direct deposition from local sources (the valley walls), and 78 percent is derived through suspension deposition from both local sources and upstream.

The relative contribution of sediments through suspension deposition is likely an upper estimate, because in localized areas the original river channel does contain thicker accumulations. Within Brownlee Reservoir, accumulation patterns appear thicker in three areas: at the dam, south of the Powder River confluence, and at a segment farther to the south (fig. 5). The segment at the dam would correspond to the area of longest inundation - representing a longer accumulation history — and more active flow during early drawdown and flooding cycles. The area of thicker sediment accumulation south of the confluence of the Powder River could be related to fine-grained sediment input from the Powder River itself. Although the southern segment is technically upstream from the source, with no currents in the reservoir to drive sedimentation patterns, the accumulation could represent higher sediment concentration. It is difficult to speculate about thicker accumulation of sediment at the southern segment of Brownlee Reservoir. The area is bordered by higher relief (for example, Sugarloaf Mountain and McChord Butte) with larger and more numerous tributaries (for example, Connor, Wolf and Fox Creeks) than downstream areas; therefore the higher accumulation of sediments could represent increased fluvial deposition. This area (around river mile 315) also corresponds to the minimum pool of the reservoir where, during years of high drawdown, upstream sediments are deposited. 


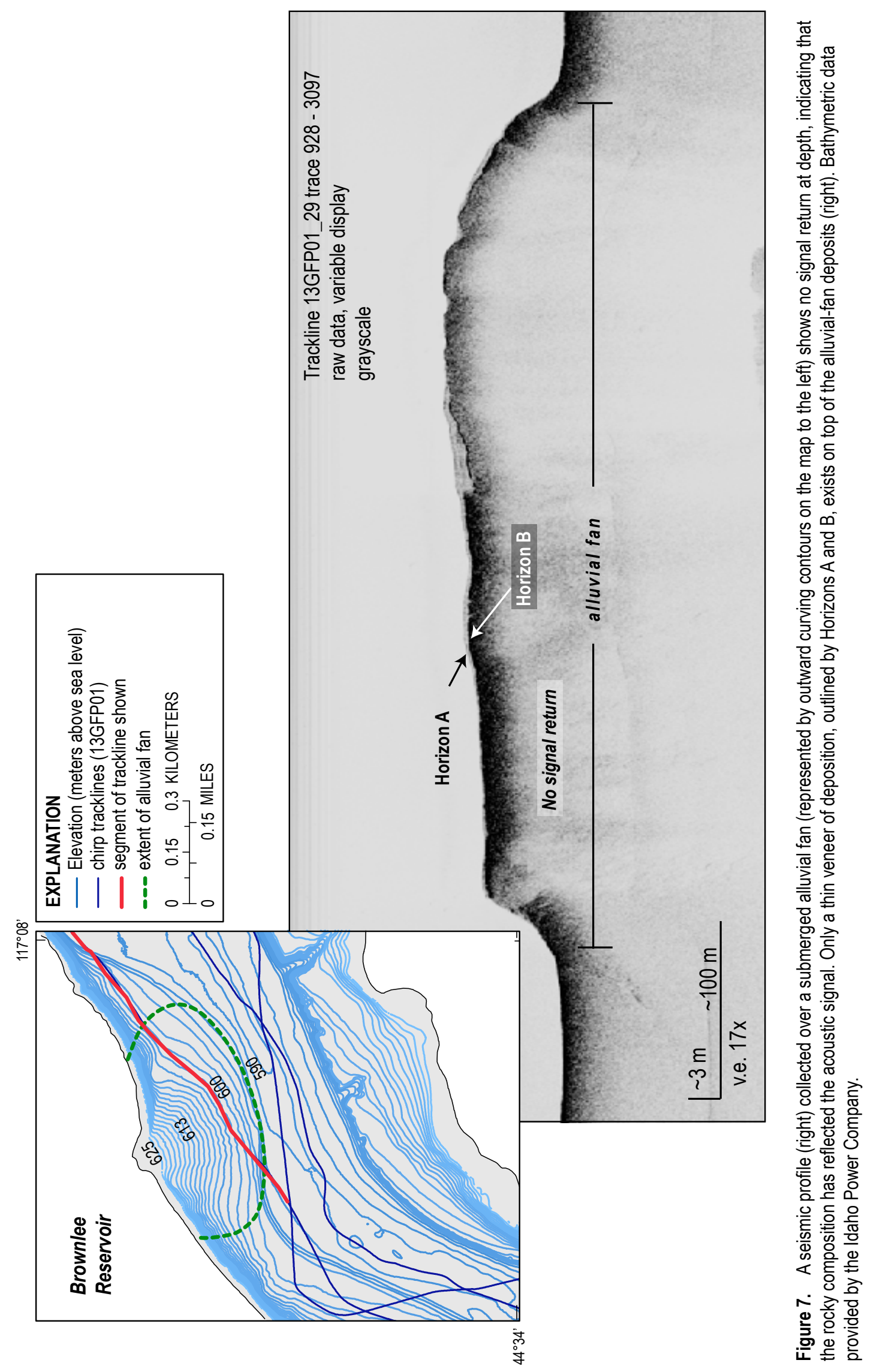



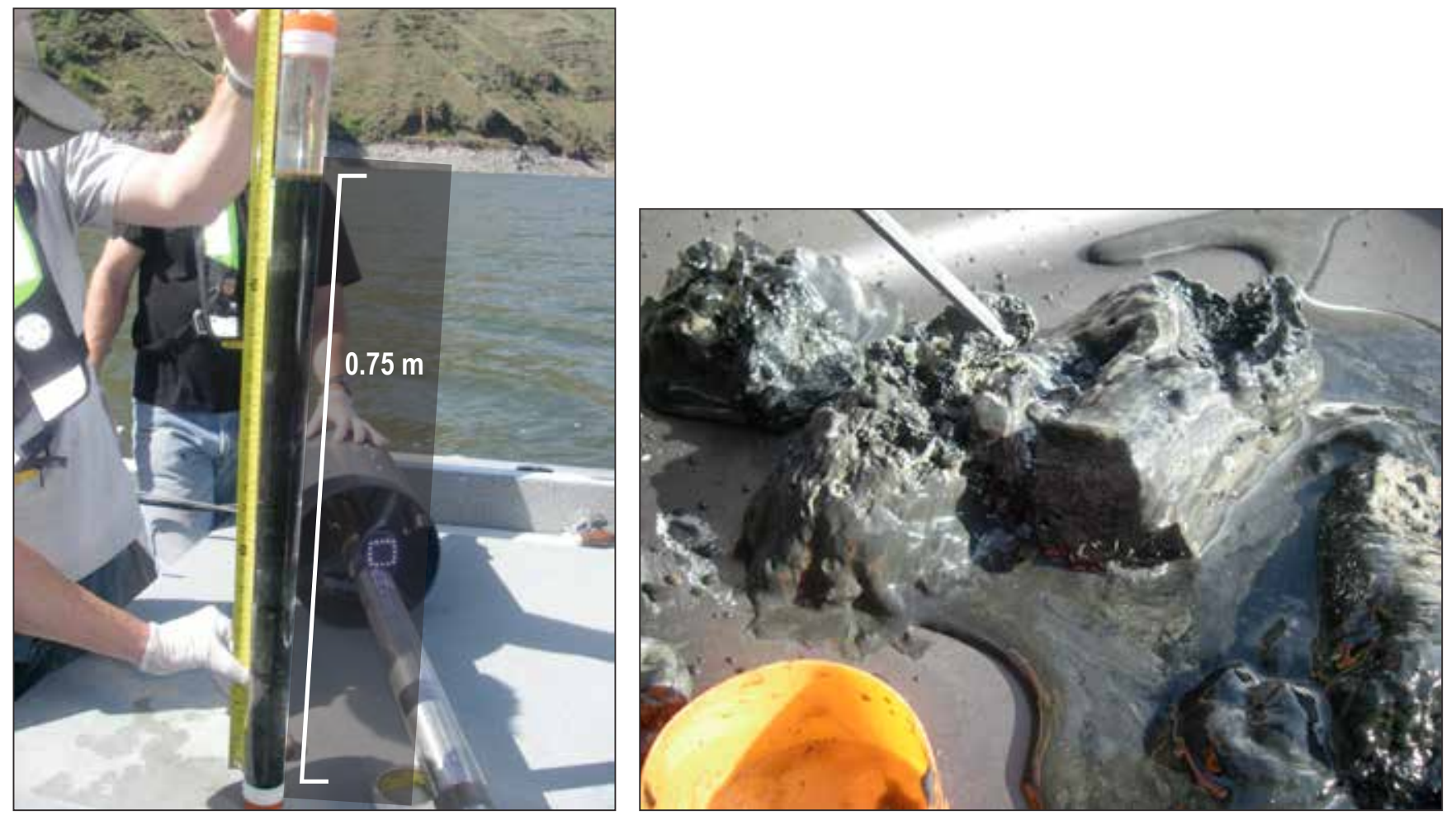

Figure 8. Gravity cores collected from deeper areas of Brownlee Reservoir yielded 0.75 meters of highly fluid muds (Clay + Silt content $=90-100$ percent). Photos provided by the USGS.
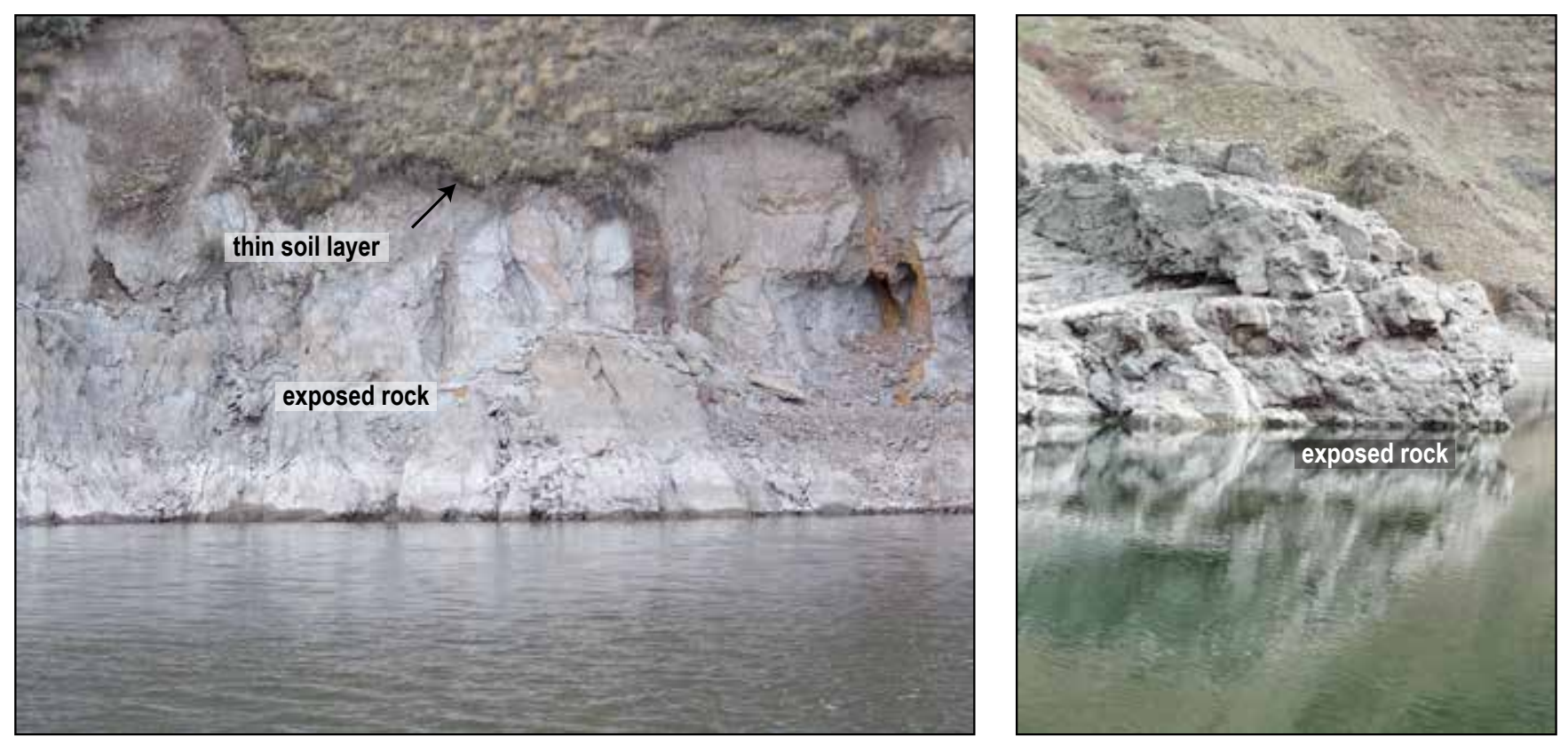

Figure 9. The valley walls at the waterline within the reservoirs show rock exposed during lake level fluctuations. During inundation, wave action scours the thin layer of soil from the rock surface and the sediment is deposited at lower elevations in areas of low relief. Photos provided by the USGS 
As with the Brownlee Reservoir, the Hells Canyon Reservoir shows an area of high relative accumulation at the dam, which corresponds to the area of longest inundation and more active flow early in the history of the reservoir. Hells Canyon has a slightly higher overall volume per unit area than Brownlee Reservoir (table 1), with direct sediment deposition from local sources amounting to $4.5 \times 10^{5} \mathrm{~m}^{3}$ of material. This suggests that an upper estimate of 86 percent of the post-construction dam deposition within the reservoir is through suspension deposition from local and upstream sources, and 14 percent is derived directly from the valley walls and local streams.

\section{Conclusion}

This study shows that chirp geophysical profiling can be used to map post-construction dam sedimentation within the Brownlee and Hells Canyon Reservoirs, which can then be used to estimate volumes of sediment accumulation. The chirp profiles from the reservoirs do not show any significant stratigraphy related to pre-dam fluvial processes. This is likely due to the low power of the system and the acoustically impermeable basalt and metamorphic rock that floor the river valleys. Clastic deposits such as alluvial fans and gravel bars (Miller and others, 2003) are similarly rocky in composition and reflect the signal. Overlying this substrate, very thin (less than $2.5 \mathrm{~m}$ ) discontinuous deposits are apparent in the profiles. The acoustic pattern of the signal is consistent with sediment textures found in cores collected from the Brownlee Reservoir, which contain very fluid silts and clays. Sharp contrast in acoustic amplitude between the water and sediment surface and between the base of the sediment surface and underlying rock substrate allowed for deposition to be isolated and quantified. Sediment deposition within the valleys appears to be low, with restricted upstream contribution, negligible currents, and a thin supply of erosive material from the valley walls. The primary processes of sediment distribution appear to be the introduction of very fine-grain material from upstream, and erosion from the valley walls during water level fluctuations. Suspended sediments from these processes settle out of the water column after extensive time. However, lower accumulation per unit area within the original Snake River channel, relative to the river flanks, suggests some direct deposition (for example, gravity flows) from local sources occurs as well. An estimated 78 to 86 percent of total accumulation within the reservoir is through suspension deposition, from both local and upstream sources, with the remainder derived directly from the valley walls and streams.

Wave scour during initial flooding and drawdown events may have redistributed the deposits from areas of high relief, which can be extreme in these valleys. The deposits drape areas of lower relief such as the pre-dam flood plain within the valleys, where they lie undisturbed due to the lack of currents. Discrete areas of slightly higher sediment accumulation are evident in isopach maps of the surface deposits (fig. 5). These deposits are 1 to $3 \mathrm{~km}$ in length and occur in areas with a longer flooding history (at the dams), areas adjacent to stream confluences (for example, Powder River), and areas most impacted by water level fluctuations (southern reach of Brownlee Reservoir at river mile 315). 


\section{References Cited}

Edgetech, 2011, Edgetech sonar data file format - Description of the Edgetech (.jsf) file format: West Warehame, Mass., published by author, document no. 990-0000048-1000, revision 1.13/September 2011, accessed October, 2013 at http://www.edgetech.com/docs/048-EdgeTech-JSF-File-Format.pdf

Forde, A.S., Dadisman, S.V., Flocks, J.G., Fosness, R., Welcker, C., and Kelso, K.W., in press, Archive of digital chirp subbottom profile data collected during USGS cruise 13GFP01, Brownlee Dam and Hells Canyon Reservoir, Idaho and Oregon: U.S. Geological Survey Data Series.

Miller, Steve, Glanzman, Dick, Doran, Sherrill, Parkinson, Shaun, Buffington, John, and Milligan, Jim, 2003, Geomorphology of the Hells Canyon reach of the Snake River (revised July 2003): Boise, Idaho, Idaho Power Company, Technical Report, Appendix E. 1-2, FERC no. 1971, variously paged (Also available at $h t t p: / / w w w . i d a h o p o w e r . c o m / p d f$ s/Relicensing/hellscanyon/hellspdfs/techappendices/ Sediment/e01 02.pdf.)

Norris, M.W., and Faichney, A.K., eds., 2002, SEG Y rev 1 Data Exchange format, SEG Technical Standards Committee, Release 1.0, May 2002: Tulsa, Okla., Society of Exploration Geophysicists, 45 p., accessed October, 2013 at http://www.seg.org/documents/10161/77915/seg_y rev1.doc.

U.S. Environmental Protection Agency, 2000, National water quality inventory-1998 report to Congress: Washington, D.C., Office of Water Regulations and Standards, EPA841-F-00-006, 45 p. (Also available at http://water.epa.gov/lawsregs/guidance/cwa/305b/98report index.cfm.) 